\title{
GEOKRIITIKAST PEIPSI JÄRVE NÄITEL
}

\author{
EVELYN FRIDOLIN
}

$\mathrm{P}$ eipsi järve kohta leidub sajandite jagu tekste eri rahvusest autoritelt. Nn Peipsi-kirjandus algas XVI sajandil saksa rännumehe Samuel Kiecheli reisikirjadega ning jätkus saksa ja vene reisikirjade, samuti luulevormis meeleolupildikestega kuni XIX sajandi keskpaigani. Siis lisandusid teekonnamuljetele eestlaste kodupaigakuvandid, olgu näiteks Juhan ja Jakob Liivi ning Anna Haava looming. Peipsi äärde jõudis ka eesti rahvuseepose „Kalevipoeg” nimitegelane. Noores Eesti Vabariigis rändasid Peipsil ja selle ääres lisaks rannarahvale kaugemalt pärit eestlased: Johannes Maide, August Gailit, Villem Ridala, looduskirjanik Johannes Piiper, kes ka oma rännumuljed jäädvustasid. Samal ajal ilmus Vjatšeslav Šiškovi üsna eestlastevaenulik teos „Sealpool Peipsit” (1926), milles ühena esimestest kujutatakse järve kahe väga vastandliku rahva ja kultuuri eraldajana. Pärast Eesti okupeerimist kirjutas Bernard Kangro paguluses teose „Peipsi” (1954), milles järvel on samuti tugev eraldav tähendus. Kodu-Eestis oli nõukogude ajal Peipsi-kirjanikuks Paul Haavaoks oma luulevormis kalurikülapildikeste ja -mõtisklustega. Pärast XX sajandi lõpu väikest mõõna ${ }^{1}$ algas Peipsi-kirjanduse uus tõus 2000. aastatel, mil eesti kirjanduses üldiselt hoogustus perifeersete paikade kujutamine. Järvest on viimastel aastatel kirjutanud Valdur Mikita (2013), Andrus Kasemaa (2008, 2012), Vahur Afanasjev (2015) ja Mari Vallisoo (2013), aga ka Peipsi-äärsed vene- ja eestikeelsed kodukohaluuletajad, kelle looming on esindatud koguteoses „Peipsi hing” (2007).

Artikli eesmärgiks on geokriitika abil Peipsi-kirjanduses orienteeruda ja seda mõtestada. Geokriitika on selline kirjandusuurimise viis, mis minetab autorikesksuse ja on seega väga sobilik meetod analüüsimaks tihedamalt läbikirjutatud paikasid. Linnade kõrval on just Peipsi ja Peipsimaa üks läbi aegade märkimisväärsel määral kirjanduslikult kujutatud paiku.

\section{Geokriitikast}

Geokriitika juured ulatuvad 1980. aastate ruumilisse pöördesse, mille idee pärineb omakorda Michel Foucault' juba 1967. aasta loengus käsitletud eemaldumisest Teise maailmasõjani vallanud positivistlikust, ajaloole keskenduvast mõtteviisist (vt Foucault 1984). Kui positivistliku mõtteviisi kohaselt kulges aeg lineaarselt progressi suunas, siis Albert Einsteini üldrelatiivsusteooria laiemasse teadvusse jõudmine ning Teise maailmasõja õudused panid inimesi niisuguses idees kahtlema. Selle asemele tuli postmodernistlik arusaam progressi võimatusest ning aja fragmentaarsusest, raskesti mõistetavusest. Ajast olulisemaks sai ruum. (Westphal 2011: 11-12)

1 Sajandi lõpust võib leida vaid üksikuid Peipsi mainimisi Mari Vallisoo luules: „Lepatriinu ja tuul” (1975, ilmunud: 2015: 44), „Kuu” (1983: 29-30), „Kodavere” (1991: 7) ja „Keväde Kodaveren” (1991: 28). 
Ruumilise pöördega samal ajal edenes geotehnoloogia, mis samuti muutis ruumitunnetust. Postmodernne globaliseerunud ruum pole aga sugugi enam üheselt määratletav, kuna näiteks ruumis liikumise kiirus ei pruugi sõltuda üldse distantsist, vaid hoopis infrastruktuuridest, aga ka sellest, kas distantsi sisse jääb piiripunkte, mille ületamisega võib juhul, kui viisasid või sissesõidulube tuleb hakata pikalt ette taotlema, muutuda muidu ahta ruumi läbimine mitmekuiseks (Tally 2013: 13-16). Piiride ületamise kiirus sõltub muuhulgas ka sellest, kust inimene pärit on, ja see seab riigid ruumilisse hierarhiasse. Niisugused ruumitaju muutused on mõjutanud nii ruumi kujutamist kunstis ja kirjanduses kui ka teaduslikke käsitlusviise (Tally 2013: 37-43).

1990. aastatel arenes oluliselt ka kultuurigeograafia, mille huvivälja on tõusnud ruumi representatsioonid nii filmis, kunstis kui ka kirjanduses (Sooväli 2008: 654-656). XX sajandi alguses omaette valdkonnana välja kujunenud kirjandusgeograafia omandas praeguse kuju samuti 1990. aastatel, kui itaalia kirjandusteadlaselt Franco Morettilt ilmus 1997. aastal teos „Euroopa romaani atlas, 1800-1900” („Atlas of the European novel, 1800-1900”), kus kirjandusteoste käsitlemise käigus koostatud kaardid teoste tegevuspaikadest ei ole vaid illustratsioonid, vaid on osa sündmustiku analüüsist (Piatti jt 2009: 182). Kirjandusgeograafia eesmärgiks ongi tuua teoste kaardistamise kaudu välja ruumilisi tähendusi, mis lugedes nii ilmselged ei ole (Piatti jt 2009: 182).

Ometi leidis prantsuse kirjandusteoreetik Bertrand Westphal veel XXI sajandi alguseski, et ruumilises pöördes ja geograafia arengus on häbiväärselt vähe tuntud huvi ruumi kirjanduslike representatsioonide vastu. Selle parandamiseks panigi Westphal oma 2005. aastal ilmunud artikli „Geokriitiline lähenemine kirjandusele” („Pour une approche géocritique des textes”) ning 2007. aastal avaldatud monograafiaga „Geokriitika: reaalsed ja fiktsionaalsed ruumid” („La Géocritique, Réel, Fiction, Espace”, ingl „Geocriticism: Real and Fictional Spaces”, Westphal 2011) aluse geokriitikale. Oma uuenduslikus teoorias toetub Westphal suuresti varasemate kirjandusteadlaste ja filosoofide Michel Foucault', Henri Lefebvre'i, Gilles Deleuze'i ja Félix Guattari, Mihhail Bahtini ning geograafide Yi-Fu Tuani, Edward Relphi ja Edward Soja töödele. Niisiis on geokriitika kasvupinnas silmatorkavalt interdistsiplinaarne. Geokriitika on just postmodernsele fragmenteerunud ruumile kohane meetod, püüdes ületada mis tahes distsiplinaarseid piiranguid ning olukordi, kus analüüsitaks ainult ühe autori või ka ühe rahvuse vaadet ruumile. Selle asemel eelistab geokriitiline lähenemine võimalikult laia pilku - mitte ainult maastikul kodus olevate, vaid ka sealt läbi reisijate, (rahvus)vähemuste nägemusi jms. Westphal sätestas geokriitika neli põhielementi: 1) vaatepunktide paljusus (ingl multifocalization), 2) aistilisus (polysensoriality), 3) ruumi kihiline kujutlus (stratigraphic vision) ja 4) intertekstuaalsus (intertextuality) (Westphal 2011: 122).

Kuigi Westphali geokriitika laenab teoreetilisi elemente teistestki valdkondadest, nagu urbanistika, filmiuuringud, sotsioloogia, soouuringud, geograafia jms, on tema esmaseks uurimisobjektiks kirjandus. ${ }^{2}$ Westphali (2011: 30-34) jaoks on oluline kirjaliku ja tegeliku maailma vaheline referentsiaalne suhe (mis ei ole ilmtingimata mimeetiline): kirjanduses käsitletud ruum peab olema

${ }^{2}$ Oma hiljutises teoses „Meridiaanide vangis. Kirjandus ja moodne kunst globaliseerumise vaatenurgast” („La Cage des méridiens. La littérature et l'art contemporain face à la globalisation”, 2016) keskendub Westpahl ka teiste ruumirepresentatsiooniviiside uurimisele. 
mingis seoses reaalse ruumiga, et seda saaks „kaardistada” ja võrrelda teiste sama geograafilise paiga representatsioonidega. Viimane eristabki geokriitikat kirjandusgeograafiast: kirjandusgeograafid, nt Moretti (1997) ja Barbara Piatti (2008) uurivad seda, kuidas mingid konkreetsed teosed kaardile paigutuvad ning millised on maastikuelemendi kujutamist mõjutavad sotsiaalpoliitilised, geograafilised ja ajaloolised tegurid, pakkumata tekstilistele kujutustele võrdlevat lähenemist rohkemal määral, kui seda võimaldab erinevate tekstide samale kaardile paigutamine. Kirjandusgeograafide uurimiskeskmes on ruum, geokriitikutel aga ruumi representatsioon.

Sealjuures nendib Westphal (2011: 75-110), just nagu (kirjandus)geograafidki, et ruum ei ole staatiline - see, millisena mingit paika nähakse, muutub ajas, nagu ka paik ise.

Ajaliste nihete ja lugeja tajutava või ettekujutatava ning kirjutatud ruumi (muuhulgas ajaliste) erinevuste tõttu toimub tekstis teatud vilkumine (ingl transgression) reaalse ja fiktsionaalse maailma vahel, reaalsest ruumist saab omamoodi „kolmasruum”. ${ }^{3}$ Selliste mitmuslike ning paradoksaalsete „kaartide" lugemist peabki Westphal (2011: 37-41) üheks geokriitikute ülesandeks.

Lisaks Westphalile on hakanud geokriitikaga tegelema teisedki kirjandusteadlased, kellest igaüks on lisanud sellesse uusi nüansse ja võimalusi. Üheks olulisemaks geokriitilise teooria edendajaks on Robert Tally Jr, kes seob tekstuaalsete ruumide uurimise tihedamalt nende sotsiaalse ja ühiskondliku kontekstiga, lähendades geokriitikat kirjandusgeograafiale. Tally toob geokriitika uurimisobjektiks ka geograafilise ruumiga seostamatud utoopilised maastikud, mis on samuti juba varem kirjandusgeograafidele huvi pakkunud. (Tally 2013: 113, 144-150)

Teiseks geokriitika edasiarenduse suunaks on lähenemine nn geopoeetikale, mis püüab leida seoseid kirjandusteose vormi, kujundite ja maastiku vahel. Sellega tegeleb nii Tally (2013) kui ka taani kultuuriteoreetika ja kirjandusteadlane Sten Pultz Moslund (2011), kes kasutab oma analüüsis mõisteid langscape (keelestik) ja landguage (maakeel). Moslundi (2011: 30-41) järgi on langscape maastikukuvand, mis lugejale tekstist tekib või mida ta autori kujutatud maastikust lugedes tajub, landguage tähistab keelt või keelelisi vahendeid, mida autor kasutab oma teoses maastiku kujutamiseks, mille abil ta „maalib” maastikku või teeb selle lugejale ettekujutatavaks.

Kolmandaks suunaks on ruumipraktikate uurimine sellistes kirjanduslikes ruumides, mida on raske kaardistada - kodustes ruumides ja perifeeriates. Sellega tegeleb näiteks California kirjandusteadlane Eric Prieto (2011). Robert Tally hiljuti algatatud raamatusarjast „Geocriticism and Spatial Literary Studies" võib leida mitmesuguseid geokriitika ruumiteoreetilisi edasiarendusi ning rakendusi. Peipsi-kirjanduse käsitlemisel olen lähtunud Westphali-Tally suunast, kuna see on siiski geokriitika lätteks ja tuumaks, samuti on see kõige referentsikesksem - ja seega Peipsi-kirjanduse puhul hõlpsasti rakendatav, pakkudes välja lahenduse sellise ulatuslikult läbikirjutatud maastikuüksuse analüüsiks.

${ }^{3}$ Edward Soja termin Thirdspace ruumide kohta, kus reaalsus ja fiktsionaalsus on kokku sulandunud. Firstspace oleks tema järgi reaalne materiaalne ruum, Secondspace viitab kujuteldavale ruumirepresentatsioonile (Soja 1996: 6). 


\section{Geokriitika neli põhialust ja Peipsi}

Kuigi leidub kirjandusteoseid, mille tegevustik toimub Peipsi järvel, on enamikus teostest Peipsi pigem koht, mis paikneb maismaal asuvate tegevuspaikade vahetus läheduses. Niisiis olen analüüsi hõlmanud lisaks järvele ka selle lähiümbruse kujutused. See, kui realistlikult püüab iga autor Peipsit kirjeldada, sõltub muidugi selleks valitud žanrist. Geokriitika valguses pööran aga rõhuasetuse veidi ümber ning tõstan olulisemaks selle, kelle vaatenurgast järve on kujutatud, kuna selle kaudu saab selgeks ka see, miks on vastavat žanri kasutatud.

1. Vaatepunktide paljususes eristab Westphal (2011: 122-131) endogeenset, eksogeenset ja allogeenset vaadet ruumile. Endogeenne vaade tähendab kohaliku inimese pilku. Kuna see eeldab autori kodusolekut kirjanduslikuks kujutamiseks valitud paigas, seob see loomingulise ja autobiograafilise ruumi. Kodukohast kirjutades valivad autorid välja subjektiivselt tähenduslikemad ruumielemendid, mida oma tekstis edasi anda. Niisiis võiks endogeensest perspektiivist lähtuva ehk kohalike kirjanduse siduda kirjandusliku omailma mõistega. ${ }^{4}$ Kohalike ruumikujutus tervikuna on justkui mitmete oma-ilmade kogum. Endogeense vaate esindajateks on nt Anna Haava, Juhan Liiv, Jakob Liiv ja Andrus Kasemaa, olulised on ka Peipsi-äärsed venelased (ent ma ei pea endogeense vaate esindajateks järvele mitte väga lähedal elanud baltisakslasi Lisa de Boori (1946) ja Fred Ottokar von Samson-Himmelstjernat (1944), nagu kaugemalt pärit eestlasigi).

Eks og e e n s lähtekohana tähistab Westphal kolonisaatori pilku teisele, võõrapärasele. Peipsi järve geokriitilises analüüsis kohandan eksogeense vaate mis tahes võõra, väljaspoolse pilguks (vt põhjalikumalt Fridolin 2015), niisiis tähendab see Peipsile ja Peipsi äärde sattunud eemalt tulija nägemust järvest. Puhtakujulist võõramaalase vaatepunkti esindavad peamiselt sakslased ja venelased, kes sõitsid läbi Eestimaa Kesk-Euroopast Venemaale või vastupidi peamiselt XVI-XIX sajandil. Mõnedeks oma teekonna kirja pannud autoriteks on saksa reisimees Samuel Kiechel (1563-1619; vt Kiechel 1866), dekabristid Fjodor Glinka (1786-1880; vt Glinka 1971) ja Faddei Bulgarin (1789-1859; vt Bulgarin 1971) ning saksa vaimulik Johann Friedrich Woltmann (1801-1858; vt Woltmann 1833). Ent lihtsalt Peipsi ääres võõra või turistina reisivat pilku esindavad mitmed eestlasedki (nt Ridala 1921; Maide 1934; Piiper 1948).

Allogeenne vaade on Westphali järgi (2011: 128) midagi endogeense ja eksogeense vahepealset: mingist paigast kirjutav autor tunneb ennast ise seal koduselt, kuid jääb sellele paigale või sealsele elanikkonnale võõraks. Kui varem oletasin, et selline võiks olla eestivenelaste positsioon, siis lähemal analüüsil ilmnes, et Peipsimaa on paik, kus venelased ei tekita eestlastes võõristust, vaid neid nähakse seal loomulikena - seega esindavad nemadki endogeenset vaatepunkti (Fridolin 2015: 11-12). Allogeenseks vaateks võiks aga lugeda seda, kui mingi paigaga ollakse tuttav vaid tekstuaalse vahenduse kaudu. Selle parimaks näiteks on Friedebert Tuglas, kelle Alatskivi kandi

\footnotetext{
${ }^{4}$ Jakob von Uexkülli terminist Umwelt lähtudes on Brita Melts omailma mõiste lahti kirjutanud järgmiselt: tegu on „reaalse maastiku või keskkonna loomingus kehtestatud vaimse analoogiaga või koguni selle baasil kujundatud alternatiivmaailmaga. Selles maailmas võib omailma kujundavat subjekti/autorit ümbritseva tegelikkuse kirjeldamine saada kaetud väljamõeldise ähmastava ja mängulise looriga, mis hoiab ilukirjandusliku maailma täiel määral taandamisest tegelikele geograafilistele maastikele.” (Melts 2013: 399)
} 
ruumitõlgendus lähtus suuresti Juhan Liivi loomingust. Talle lisanduvad kirjandusretkelised, kes on läinud Peipsi-maile Juhan Liivi kodutalu ning Peipsit külastama ning kes tõlgendavadki kohalikku maastikku ennekõike Liivi kujutuste (ning Tuglase Liivi-retseptsiooni) kaudu. Näiteks: „Üldiselt kujutad „Varju” järgi Kitselinna hoopis viletsama pinnasega, liivaseljandikuna soos. Kirjaniku vennapoeg Karl Liiv tõdeb, et Juhan kirjeldas Kitselinna nii kui's ta oli, nüüd aga on Kitselinn kasvanud võssa ja meie ei näe seda enam nii nagu Juhan." (Prees 1959)

Peamiseks oma ja võõra vaatepunkti erinevuseks on see, millises kirjandusžanris järve kujutatakse, millega omakorda seostub see, kuidas avatakse isiklikke paigaseoseid ning maastikutunnetuse põhjalikkust. Läbireisijad kirjeldavad maastikku peamiselt visuaalsest küljest, mõnikord avavad ka paiga ajalugu. Selle edasiandmiseks kasutatakse enamasti proosat - nt reisikirju või ajaloolist romaani. Kohalikud autorid seevastu keskenduvad pigem isiklikele sidemetele paigaga ning kajastavad rohkem erinevaid Peipsiga seotud aistinguid, samuti emotsioone, mida tihtilugu väljendatakse luulevormis. Enam kui kohalikele eestlastele on Peipsi-äärsete venelaste jaoks järv oluline identiteedi alalhoiu seisukohast (nt Peipsi hing 2007: 158). Peipsi minevikust rääkides annavad kohalikud edasi oma eluloo seoseid järvega, ent läbisõitjad jutustavad järve tähtsusest ajaloos, enamasti Jäälahingu näitel (nt Rohrbach 1892; Sivers 1846).

2. Ruumi kihiline kujutlus (Westphal 2011: 137-143) on oluline mingi paiga kohta kirjutatud tekstikorpuse korrastamiseks. Paikadest kirjutamise viis muutub ajas. Mõnikord on määrav maastiku enda muutumine, teinekord sõltub see parasjagu valitsevast kirjutamisviisist või autori stiilist. Kirjanduse kaudu tuleb välja ka ruumi ajaline mõõde, kuna tekstis jäädvustatakse konkreetne hetk: erinevaid tekste tundes ning mineviku-oleviku maastikku kõrvutades muutub ruum justkui neljamõõtmeliseks.

Viibides näiteks Liivi muuseumi õuel ja vaadates Peipsi poole jäävat metsa, võib kujutada ennast Liivi eluaega ja mõelda selle metsagi temaaegseks, sest nüüdki varjab see Peipsit. Ent lisades sellesse kujutelma Tuglase arvamuse, et Liiv mõtles metsa oma hullusehoogudes välja (Tuglas 2013: 40-42), kuna Tuglase sealkäigu ajal (esmakordselt 1904. aastal) oli see hiljuti maha võetud, siis tühistub metsatuka Liivi-aegsus ning konkreetse maastikupildi tõlgendus jääb võnkuma eri aegadest pärit kujutuste vahele.

Ajaränd toimub ka kirjandusteoste siseselt, kui need räägivad minevikust: autor kujutab ette, milline võis tema nähtav maastik kunagi varem välja näha ja kuidas seda siis tajuti. Ruumi ajalisust võib tõlgendada Mihhail Bahtini (1987) kronotoobi mõiste kaudu, kus aeg ja ruum on üksteisest lahutamatud. Geokriitika kontekstis tundub aga kõnekam rääkida stratigraafilisest r u u mist, mis piltlikult sarnaneb pinnaseläbilõikega geoloogias või arheoloogias, kus lähtekivimi peal paiknevad erinevad mullakihid oma sisseuhte- ja väljauhtehorisontidega ja kus looduslikul pinnasel lasuvad erinevate aegade kultuurkihid. Erinevus seisneb selles, et kirjanduse kultuurkihid on vaimsed ning tõlgenduslikud. Niisiis sõltub mingi tegeliku maastiku pilt ühtlasi vaataja lugemusest ning kultuurilistest taustateadmistest. Ilmselgelt on selles kujundlikus stratigraafias nähtavamal tuntumad ja kanooniliste autorite tekstid, kuna teadmised nende kohta on levinud suurema hulga inimeste teadvuses. 
3. Intertekstuaalsus (Westphal 2011: 144-147) kerkib esile siis, kui paiga kohta on juba varem midagi kirjutatud ning kirjanduslik ruum on kultuuri või rahvuse „kollektiivses mälus” piisavalt kinnistunud. Sellisel juhul hakkavad olemasolevad tekstid mõjutama seda, kuidas samast paigast edaspidi kirjutada, sest see ei ole enam paik iseeneses, vaid sel on mingisugune kultuuriline kuvand, mida saab kas kinnitada, kummutada või sellega dialoogi astuda.

Peipsile on enim intertekstuaalseid sidemeid andnud Kreutzwaldi „Kalevipoeg” ning Juhan Liivi looming. „Kalevipojale” viitavad Johannes Maide teoses „Süstal ümber Eesti” (1934: 70), Mari Vallisoo luulekogus „Viimäne vihim” (2013: 45) ning Zoja Pekarskaja luuletuses „Georg Ots” (Peipsi hing 2007: 142143). Kui Pekarskaja mainib „Kalevipoega” vaid viitena eesti mütoloogiale, mis seostub tema kodukohaga, siis otseseima Peipsi ning „Kalevipoja” seose esitab Maide (1934: 70), kellele järve lained justkui iseenesest toovad huulile värsid eeposest: „Laia laane minu tuba, / Tuules on mul tulease / Vihmas vihtlemise paika / Udus uinumise paika" (vt Kreutzwald 2011: 138).

Juhan Liivi loomingule viitavad looduskirjanduslikes tekstides Jüri Parijõgi (1937: 202-203) ning Endel Priidel (1968: 93-111). Nad seovad Liivi kodukoha tema loominguga ning mõtestavad maastikku just kirjanikust lähtuvalt: „Siinne loodus on andnud ta [Juhan Liivi] luuletustele värvi ja proosapaladele ainet. Kirjaniku fantaasia on saanud toetust just siit, Peipsi lagedalt veeväljalt, rannaliivikuilt, tagasihoidlikult, kuid ometi Peipsi ühelt kaunimalt maastikult." (Priidel 1968: 94)

Ilukirjanduslikest tekstidest esineb viiteid Liivile näiteks Gustav Suitsu (Sõnarine 1989: 389-390), Andrus Kasemaa (2008: 28, 2012: 36) ning Marta Sillaotsa (1921: 32) loomingus. Sillaots on erandlik seetõttu, et tema tsiteerib oma teose „Peipsil” alguses Juhan Liivi luuletust „Üle vee”, samal ajal kui teised viitavad pigem proosale, tehes juttu näiteks „Varjust”, „Käkimäe käost” (Suits küll ise luulevormis) ja Kukulinnast/Kitselinnast. "Varju” peategelase Villu Peipsi-igatsus seotakse Juhan Liivi Peipsi-lembusega. Juhanliivlus Kasemaa teostes ongi ennekõike Peipsi-ihalus: „Enne vihma tõusidki veed ja suur järv oli korraga kõrge ja sinine, lesed kuulasid seda kohinat kui midagi imearmast. Nagu väikesed juhanliivid olid nad kõik künka peal reas ja kuulasid seda kohinat." (Kasemaa 2012: 56)

4. Maastikukuvandi loomisel on oluline ka aistilisus (Westphal 2011: 131-135), kuna ruumi tajutakse kõigi meelte abil. Elavamate kujutluspiltide pakkumiseks kasutatakse tekstis tihtilugu sünesteesiat, sest reaalsuse kujunditul, poeetikata kirjeldamisel ei pruugi olla mõjujõudu.

Reisikirjades antakse aistilist infot edasi vahetult, luues elava olustikupildi, seda ilmekaimalt ehk Georgi Karajevi ja Aleksandr Potressovi „Peipsi järve mõistatuses” (1969) ning Johannes Maide retkekirjeldustes (1934), samuti Johannes Piiperi maastikupiltides (1948). Need paistavadki silma sellega, et lisaks visuaalsele maastikukirjeldusele antakse aimu ruumikogemuse teistest aspektidest - helidest, ilmastikuoludest, temperatuurist ning muust. Näiteks: „Summutatult kruuksudes liigub sookurgede talbjas rivi lõuna poole. Järvel valendab naeru- ja kalakajakaid [---] Kilgates liugleb neid õhus ja ujuskleb helkiva s vees." (Piiper 1948: 183; minu rõhutus $-E$. F.) Ilukirjanduslikes žanrites omandavad aistingud aga metafoorse paik.

${ }^{5}$ Kitselinn kui geograafiline paik ja Kukulinn kui tolle baasil kirjutatud fiktsionaalne 
tähenduse. Juhan Liivi „Varjus” tähistab Peipsi kohisemine kättesaamatut igatsust, mida rõhutab asjaolu, et järv ei paista metsa tagant. Peipsi on samal ajal väga tuttav ja tundmatu - helid teevad selle tuttavaks, ent silmale järv ei paista: „Ta [Villu] ei teagi, mis asi järv on: ema ütleb, et metsa taga on suur vesi ja see võib nii imelikult k o h a d a... Tõesti peab ta suur, vägev asi olema, see suur vesi." (Liiv 2008: 45; minu rõhutus $-E$. F.)

\section{Sümboltähendused}

Geokriitika on rõhutatult ruumikeskne meetod (Tally 2013: 141-142), mis pöörab tähelepanu sellele, milliseid kuvandeid uuritav koht esile kutsub, kuidas üht ja sama kohta representeeritakse. Peipsi vaatlemisel geokriitika nelja elemendi kaudu ilmnevad järve erinevad sümboltähendused, samuti see, kuidas Peipsit on abstraheeritud kolmel tasemel: Peipsi kui koht, Peipsi kui mittekoht ${ }^{6}$ ning kõige mõttelisemas tähenduses on järv kaotanud oma ruumilisuse ja muutunudki sümboliks või abstraktsiooniks, mille olen antud juhul nimetanud mitteruumiks. Koht oleks siinkohal selgesti määratletav ruumiosa, maa-ala kaardil. Mittekohana võiks mõista niisugust ruumi, mis ei toimi koha või paigana, milles ei saa „kohal olla” - siia alla kuuluvad piirid ja orientiirid, ühendusteed. Mitteruumi all mõistan ruumist tekkinud mitteruumiliste kvaliteetide - tunnete, identiteedi, igatsuste, müstilisuse - kogumit.

\section{Peipsi kui koht}

Keskkonnana kannab Peipsi järv ennekõike tausta andvat, miljööd visandavat tähendust (järv on vaatepilt, mida kirjeldatakse), siiski on koht oluline ka mineviku kujutamisel ja inimeste ning keskkonna vaheliste seoste markeerimisel. Tekstide vaatlusel selgub, et see, kas Peipsit on teoses kujutatud endogeensest või eksogeensest vaatepunktist, tingib ühtlasi selle, millist laadi aistilist infot tekstiga edasi antakse, millist žanri eelistatakse ning milline on teksti eesmärk. Samuti sõltub vaatepunktist see, kas ja kui tihedalt on kirjutaja identiteet seotud selle paigaga, millest tekstis juttu on. Eksogeensest perspektiivist lähtunud maastikukirjeldused, enamasti reisikirjelduste vormis, annavad edasi mitmekülgset kogemuslikku infot. Endogeenne pilk väljendab pigem tundeid kodu- või lapsepõlvemaastiku vastu ning minevikulise maastiku kujutamiselgi kirjutatakse eeskätt oma isiklikust minevikust seoses järvega. Viimasel juhul võrdub Peipsi enamasti lapsepõlve ideaalmaastikuga, mis on eriti esil kogumiku „Peipsi hing” autoritel, nt: „Kodujärv Peipsi / sündisin ja kasvasin ma seal. / Missugune sinine taevas, / Missugune udu järve kohal! // Millised koidud, ehad - / Kauge nooruspõlve unistused. / Siledal veepinnal - lodjad purjelised. / Armas lapsepõlv - kus oled sa?"' (Peipsi hing 2007: 232; toortõlge - E. F.) Kaugemat minevikku või mingeid ajaloo sõlm-

\footnotetext{
${ }^{6}$ Marc Augé (2012) termin koha või paiga jaoks, mida ainult läbitakse, kuid kus kunagi ei „koduneta” - nt lennujaamad, teed, piirid.

7 „Родное озеро Чудское, / Родился я и вырос там. / Какое небо голубое, / Какой над озером туман! // Какие зори, а закаты - / Далёкой юности мечты. / Над гладью - лодьи парусаты. / Родное детство, где же ты?” 
punkte (Jäälahingut, Eesti iseseisvumist) käsitlevad nii endogeense kui ka eksogeense vaate esindajad.

Inimesed ja neid ümbritsev keskkond on seotud kahel viisil. Esiteks autor tajub inimesi maastiku osana, see on tunnuslik nii kohalikele kui ka paigaga vaid põgusalt tutvunud autoritele. Kaldarahvas on justkui osa vahetust olustikupildist: „Taas värisevad kobrulehed / ja roostik hõljub lainetes... / Näe, juba tulevadki mehed, / on lained paadinina ees! / Sõud järvepeegli puruks lööb / ja paati saadab hele vööt..." (Haavaoks 1957: 31) Teiseks - minajutustaja ise sulab Peipsiga ühte. Seda kohtab luulelaadis, mis on omane Peipsi-äärsetele venelastele. Järvest lähtub nende enesemääratlus, näiteks seab Olga Kereketkina oma vanausulise identiteedi aluseks Peipsi, seda ristimisnõu metafoori kaudu: „Ime-järv, Peipsi! / Sa mu ristimisnõu. / Usult olen - vanausuline. / Vanausulised on vaimult tugevad." (Peipsi hing 2007: 158; toortõlge $-E$. F.)

\section{Peipsi kui mittekoht}

Mittekohana hõlmab Peipsi järv kolme tähendust: piir, ühendustee ja orientiir.

See, kuidas ja mil määral tajutakse Peipsit piirina, sõltub ajalisest kontekstist. Riike eraldav tähendus tuleb enim esile Eesti Vabariigi alguskümnendeil loodud või seda perioodi käsitlevates eesti- ja venekeelsetes teostes. Saksa ja baltisaksa autoritel on esil pigem kultuuriline piir Balti ja Vene alade vahel, samuti kirjutavad nad järvest kui Saksa ordurüütlite kaotuse ja Vene vägede võiduga lõppenud Jäälahingu õudsest toimumispaigast. Näide siin läbisõidul olnud baltisaksa mõisniku Jegor Julius von Siversi teosest „Lahing Peipsi järvel”: „Kahvatu läikega maalib / Kuu jääväljasid / Ja annab kartlikult / Edasi kohutavat surnupilti. / Tähed helgivad veriselt / Läbi öö ääretu pimeduse. / Pakane uuristab jääd, / Mis valjult praksub."9 (Sivers 1846: 7; toortõlge - E.F.)

Kõige teravamalt on Peipsi piirimomenti käsitlenud Vjatšeslav Šiškov uudisjutus „Sealpool Peipsit” (1926) ning Bernard Kangro romaanis „Peipsi” (1954). Esimene kujutab eestlasi elajalike ja mõrvarlikena, kes teevad kõik, et venelased ei pääseks oma armastatud kodumaale, st tagasi Venemaale. Sarnane julmus kandub üle ka Peipsi kirjeldustesse: „Surm lehvitas tiivu põgenejate laagri kohal. Ümberkeeru oli kõik surnud ja vaikne, ristideta surnuaed - Peipsi - lõi oodates valgendama" (Šiškov 1926: 180).

Sama terava eristuse teeb Kangro. Käsitledes Eesti Vabariigi viimaseid aastaid ning okupatsiooniohtu, omandab ka Peipsi just järve tagant ähvardava peatse kallaletungi varjus ohtliku ning julma ilme. Peipsi ääres leiavad aset tulekahjud, nõiaks peetav tüdruk Marta näeb und leegitsevatest hobustest, kes üle Peipsi Eestisse tulevad: „Üle järve tulevad punased hobused... Otse üle vee... üle laia vee... kaugelt. Neid on palju. Tuleb ikka rohkem ja rohkem. Kogu vesi on täis. Kallas on täis... Lakad lehvivad... kabjad peksavad vett... Soo on neid täis... mets... Nüüd nad tulevad... lähenevad..." (Kangro 1954: 92)

\footnotetext{
8 „Чудо-озеро, Чудское! / Ты купель моя крестильная. / Я по вере - староверка. / Староверы духом сильные."

${ }^{9}$ „Mit bleichem Glanz bemalet / Der Mond das Eisgefild / Und ziehet bang vorüber, / Ein schaurig Leichenbild. / Die Sterne funkeln blutig / Durch's weite Schwarz der Nacht. / Der Frost wühlt in dem Eise, / Das berstend laut erkracht."
} 
Samas on paljudes teostes kujutatud järve ühendusteena Eesti ja Venemaa, aga ka erinevate samale kaldale jäävate paikade vahel. Varasemas kirjanduses esineb Peipsi majandusliku sillana järve kaldal või sellega ühenduses olevate jõgede äärsete asulate vahel, seda eriti reisikirjades. Samuti tuleb varasemas kirjanduses juttu veeteedel liikumise raskusest, näiteks: „Kui me olime ainult 2 miili edasi liikunud, puhus tuul meile nõnda vastu, et me paremat kätt kaldal randusime; tuul oli nii kõva, et me läksime silma jäänud kalamehemajja, kuhu me jäime viieks tunniks peatuma...."10 (Kiechel 1866: 113; minu tõlge - E. F.) Edaspidigi kulgeb Samuel Kiecheli ja tema kaaslaste reis tugeva tuule tõttu vaevaliselt, lõpuks jõutakse siiski Pihkvasse.

Ühendusteena esineb järv ka Juhan Liivi jutustuses „Peipsi peal”.

Eesti Vabariigi algusaegsetes tekstides kerkib sihtpunkti jõudmise asemel olulisemaks teekond, näiteks Villem Ridala reisikirjas „Ringi mööda kodumaad” (1921) ning Johannes Maide süstaretke päevikus (1934). Ridala kirjeldab Peipsit turisti vaatepunktist järgnevalt: „Järv lainetab pisut kerges virus, kuid laevas ei ole seda tundagi. [---] Oleme üsna ranna lähedale jõudnud. Võib palja silmagagi eraldada liivase ranna, männiku veeru, mis mustates kaugusesse ulatab. // Pisut alamal on Vene küla. Armetumad mustad ja räpased unarule jäetud majad paistavad laevale." (Ridala 1921: 73) Ja hiljem Lohusuu sadamas: „Lähedal on väikesi laevu ankrus. On tundmus, nagu oleksid peaaegu merel, ainult õudne ranna maastik ja võõraste külade vaade ei lase tähelepanu eksida." (Ridala 1921: 74)

Orientiirina aitab Peipsi eksogeense vaate esindajatel muidugi määratleda Peipsi-lähedaste paikade asukohta, kuid ühtlasi defineerida kogu Eesti ala. Näiteks baltisakslaste Fred Ottokar von Samson-Himmelstjerna (1944) ja Lisa de Boori (1946) teostes nimetatakse Eestit Peipsi-äärseks maaks. Võimalik, et selline mitte Eestist üldisemalt lähtuv, vaid just Peipsil põhinev määratlus tulenes ida poolt lähenevast Vene ohust, mis autoreile mõjus ning mis tekstide ilmumise ajaks oligi juba hävitanud Eesti iseseisvuse ning baltisaksa kultuuri viimased riismed.

Kohalike autorite teostes külgneb järv lihtsalt nende kodukohaga. Orientiirina esineb Peipsi Mari Vallisoo luuletuses, kus järve kohisemine aitas lüürilisel minal leida kodutee: „Kuulin - järv jo kohisi / siis saen selgess, kost / vaja mennä Ämmäle / saema ommokost" (Vallisoo 2013: 64).

\section{Peipsi kui mitteruum}

Eriti just kohalike kirjutatud tekstides omandab Peipsi tihti müstilise mõõtme, millega järv minetab oma maastikulisuse ning üleneb hoopis igatsuse, üliinimlikkuse, saatuse või nõiduslikkuse võrdkujuks. Sellist ruumilise konkreetsuse hajumisel tekkivat sümboltähenduslikku Peipsit nimetan mitteruumiks, mille all eristan järve pühalikku ja nõiduslikku ilmet.

Peipsi pühalikkus esineb ühelt poolt müstilisusena, saatuslikkusena - kohati peaaegu religioosse mõõtmena, ent see võib ilmneda ka armastuse kujutisena. Peipsi on aga kättesaamatu armastus. Heldi-Irene Sepa luuletu-

10 „Als wür nun bey 2 meil in düe seh kamen, wendet sich der wündt unns entgögen, das wür unns zur rechten hand dem landt zue begaben, wurd der windt so starckh, das wür an das landt fuehren zu einem einzechtigen vischerhaus, do wür dann bey finf stundt lanng verbliben...." 
ses kujutab naine Peipsit oma peiuna: „Minu kallis Peipsi, / Miks seisad sa täna nii mõtetes / Tahtsin su lähedal olla / Ja tulin rutates. [---] Nüüd olen siin / Sina ilusaim Peipsi peig / Võta mind oma sülle / Kallista, olen Sinu leid..." (Peipsi hing 2007: 81). Naine vestab Peipsiga, kes millegipärast ei rõõmusta oma neidu nähes, ning järgnev luuletus „Vihane Peipsi” seletab veekogu pahameelt: „Su südames on armastus / vist jahtund, / Su lainetes on palju / valget vahtu. / Sa oled kuri, et nii kaua / olin ära.” (Peipsi hing 2007: 82)

Pühaduse taju on omane kohalikule rahvale - endogeense vaatepunkti esindajatele, ja selle väljendamisel mängib muuhulgas rolli näiteks see, et nägemismeele usaldusväärsus mingil hetkel hajub, valitsema pääsevad järve teised omadused, näiteks helilisus. Ka Anna Haava luuletuses „Kuulsid sa ehk lainte laulu?” on visuaalse ja helilise info vahel kontrast: „Kuulsid sa ehk lainte laulu, / Mis nad udu hämarusel, / Pikkerpilli puudutusel, / Tuulte, tormi tõusemisel / Kuuldavale kohisevad? // Ehk mis koidul kuulutavad, / Päikesele pajatavad, / Vahest veidi vallatavad, / Ehahiilgel unistavad, / Tähevalgel sosistavad?... // Ise sõudvad kaugemale - / Ikka igaviku poole..." (Haava 1906: 1) Lained räägivad üht juttu, ise sõuavad aga igavikku.

Lihtsat hardust Peipsi vastu ilmutavad näiteks „Peipsi hinge” autorid. Peipsi pühalikkuse parimad näited leiduvad aga Juhan Liivi loomingus. „Varjus” on järv justkui kättesaamatu ja ülim unistus. Kuigi seda näha ei ole, kuuleb peategelane Villu pidevalt järve lähedalolu. Peipsi ulatub inimesteni, inimesed Peipsini aga mitte - küla ja järve vahele jääv mets toimib müürina, mis ei lase Kukulinna elanikel Peipsi ülevusest osa saada. See panebki Villu nukralt lausuma: „Kui seda metsa ees ei oleks!...” (Liiv 2008: 114) Kättesaamatus aga annabki järvele pühaduse.

Liivi novell „Peipsi peal” loob kuvandi ohtlikust ja ähvardavast Peipsist. Üle laguneva jääga järve tulevad mehed tunnevad pidevat hirmu oma saatuse pärast ning järv mõjub neile suure, hoomamatu - mere sarnasena. Siingi puudub visuaalne informatsioon ja oluline on helilisus: kuna nähtavus on halb, kuid kuulda on jää praksumist ning vee vulinat, tundub olukord eriti hirmsana. Nõnda pöörduvadki mehed palvetes jumala poole, et see nad päästaks Peipsi raamib siin saatuslikkust ja religioossust. Kuigi sarnaselt oudsena mõjub ka Kangro kujutatud Peipsi, mida käsitlesin mittekohana, on kummagi järvekuvandi põhjused ometi erinevad. Liivil on esikohal järve enda ohtlikkus ja õudsus (mitteruumilisus), Kangrol peegeldab järv selle taha jääva Venemaa julmust - piirijärvena see siiski ka ühendab.

Ka Jakob Liivi novellis „Jää tulek” võib kuulda palveid, kui jää hakkab maa peale tungima ning kuure ja elumajugi lammutama: „Neist kivide ümber kogunenud jäätükkidest ehitab kangelane enesele silla, mille kaudu hõlpsamini maale pääseda. Ristimärki rinnale tehes ja jumalat paludes lõhuvad mehed tuuradega maale tungivat jääd, aga kangelane ei kohku, ei tagane inimese nõrga jõu ees! [---] Võimus on kangelasel. Kõige enne langevad vihtlemissaunad... [---] Nende järel tuleb kord tindikuivatusahjudele ja elumajadele. [---] Nagu kangelase sõrme liigutusel langeb maja maja järel maha ja hiiglasuured jäävirnad asuvad nende asemele.” (Liiv 1960: 369-370)

Nõiduslikuna kujutavad Peipsit kaugemalt tulijad - eksogeense vaate esindajad, kes järve külastades jäävad selle aura kütke - ning see avaldub kahel viisil. Esimesel juhul on järv personifitseeritud nõiaks, nagu näiteks Maide reisikirjas nõid Peipia kujul: „Kuid varsti algan uuesti ühes „Numiga” [süsta 
nimi] võitlust Peipia vastu. Igivõlur - nõid on aga tugevam ja varsti pean jälle maabuma. Uuesti tormijooks tormi vastu - kuid uuesti ka tagasilöök." (Maide 1934: 62-63) Teisel juhul lasub Peipsil nõiduslik aura, mille lõksu järve ääres olevad inimesed satuvad ja mis mõjub neile lausa uimastavalt. Näiteks kirjeldab Vahur Afanasjev (2015: 13) nõiduslikku aurat, mille kütkeist päästab tuppa jõudes sisselülitatav televiisor, justkui taastaks see normaalolukorra ning kaotaks Peipsist tekkinud reaalsuse nihestatuse.

\section{Kokkuvõtteks}

Analüüsides Peipsi-kirjandust geokriitilise meetodiga, tulid selgelt välja ruumi kujutamise erinevad abstraktsuse tasemed, kus ruum esineb kas enam-vähem konkreetsena või sümbolina: Peipsi võib olla nii maastikuüksus, mittekoht piiri, ühendustee või orientiirina kui ka kättesaamatute igatsuste kehastus. Geokriitika põhielementidest oli ruumi uute aspektide väljatoomisel olulisim endogeense ja eksogeense vaate eristamine, samuti tähelepanu pööramine tekstides esinevale aistilisele informatsioonile. Mitme vaatepunkti arvessevõtmist ei saanud Peipsi-kirjanduse uurimisel tekstikorpuse mahukuse tõttu nagunii vältida. Intertekstuaalsuse märkamine aitas selgemini mõista, millised teosed on maastikul n-ö kindlamalt kanda kinnitanud ja hilisemat paigakuvandit mõjutanud: kirjanduslik Peipsi ja Peipsimaa on ennekõike ja senimaani „Kalevipoja” ja Juhan Liivi maastik.

\section{Kirjandus}

Afa na sjev, Vahur 2015. Tünsamäe tigu. Tartu: NAK.

A u gé, Marc 2012. Kohad ja mittekohad. Sissejuhatus ülimodernsuse antropoloogiasse. Tlk Anti Saar. Tallinn: Tallinna Ülikooli Kirjastus.

B a t tin, Mihhail 1987. Valitud töid. Tallinn: Eesti Raamat.

De B o or, Lisa 1946. Hell glänzt der Peipussee. Erzählung. Kassel: BärenreiterVerlag.

Bulgarin, Faddei 1971. Matk mööda Livoniat. - Postitõllaga läbi Eestimaa. Eestimaa vene kirjanike kujutuses (XVIII sajandi lõpp - XX sajandi algus). Koost Sergei Issakov. Tallinn: Eesti Raamat, lk 230-251.

Foucault, Michel 1984. Of other spaces, Heterotopias. - Architecture, Mouvement, Continuité, nr 5, lk 46-49. http://foucault.info/documents/heteroTopia/ foucault.heteroTopia.en.html (1. IX 2016).

Fridolin, Evelyn 2015. Peipsi-kirjanduse geokriitiline analüüs. Magistritöö. Tartu: Tartu Ülikool, filosoofiateaduskond, kultuuriteaduste ja kunstide instituut. http://dspace.ut.ee/bitstream/handle/10062/47837/fridolin_evelyn.pdf

Glin k a, Fjodor 1971. Kirjad sõbrale. - Postitõllaga läbi Eestimaa. Eestimaa vene kirjanike kujutuses (XVIII sajandi lõpp - XX sajandi algus). Koost Sergei Issakov. Tallinn: Eesti Raamat, lk 50-55.

Haava, Anna 1906. Lained. Tartu: Postimees. www.digar.ee/arhiiv/nlibdigar:36721

Ha a va oks, Paul 1957. Peipsi rannalt. Luuletusi 1949-1957. Tallinn: Eesti Riiklik Kirjastus.

Kang r o, Bernard 1954. Peipsi. Lund: Eesti Kirjanike Kooperatiiv. 
Kar ajev, Georgi, Potress ov, Aleksandr 1969. Peipsi järve mõistatus. Tallinn: Eesti Raamat.

Ka s e m a a, Andrus 2008. Poeedirahu. Tartu: Ilmamaa.

Ka s e m a a, Andrus 2012. Leskede kadunud maailm. Tallinn: Varrak.

Kiechel, Samuel 1866. Die Reisen des Samuel Kiechel: Aus drei Handschriften. Stuttgart: Literarischer Verein. http://reader.digitale-sammlungen.de/en/fs1/ object/display/bsb10929848_00007.html?contextType=scan\&contextSort=score \%2Cdescending\&contextRows=10\&context=beybas (1. VIII 2016).

Kreutzwald, Friedrich Reinhold 2011. Kalevipoeg. Eesti rahvuseepos / The Estonian National Epic. Tartu-Tallinn: Eesti Kirjandusmuuseum, Kunst.

Li iv, Jakob 1960. Valitud teosed. Tallinn: Eesti Riiklik Kirjastus.

Liiv, Juhan 2008. Peipsi peal. Tallinn: Eesti Raamat.

Ma i d e, Johannes V. 1934. Süstal ümber Eesti. Tallinn: Autori Kirjastus.

Melts, Brita 2013. Andrus Kasemaa kirjanduslik omailm. - Keel ja Kirjandus, nr 6, lk 393-408.

Mikita, Valdur 2013. Lingvistiline mets: tsibihärblase paradigma. Teadvuse kiirendi. Tallinn: Grenader.

Moretti, Franco 1997. Atlas of the European novel, 1800-1900. London-New York: Verso.

Moslund, Sten Pultz 2011. The presencing of place in literature. Towards an embodied topopoetic mode of reading. - Geocritical Explorations: Space, Place, and Mapping in Literary and Cultural Studies. Toim Robert T. Tally Jr. New York: Palgrave Macmillan, lk 29-43.

Parijõ gi, Jüri 1937. Alutaguse metsades. Matkamälestusi. Tartu: Loodus.

Peipsi hing 2007 = Peipsi hing. XX sajandi lõpu XXI sajandi alguse Peipsi luuletajate luulekogu / Чудская душа. Сборник стихов поэтов Причудья конца XXначала XXI в. в. Koost Fjodor Maspanov. Mustvee: F. Maspanov.

Piatti, Barbara 2008. Die Geographie der Literatur. Schauplätze, Handlungsräume, Raumphantasien. Göttingen: Wallstein.

Pi atti, Barbara, Bär, Hans Rudolf, Reuschel, Anne-Kathrin, Hurni, Lorenz, Cartwright, William 2009. Mapping literature: Towards a geography of fiction. - Cartography and Art. Toim W. Cartwright, Georg Gartner, Antje Lehn. Berlin-Heidelberg: Springer Verlag, lk 177-192. http://www.literaturatlas.eu/ files/2012/01/Piatti2008_ArtAndCartography_Springer.pdf(15. IX 2016).

Pi i p e r, Johannes 1948. Pilte ja hääli Eesti loodusest. Tartu: Teaduslik Kirjandus. Prees, A. 1959. Kilde ja killukesi matkateilt kirjanike kodudesse. - Kolhoosi Küla 29. I.

Pri et o, Eric 2011. Geocriticism, geopoetics, geophilosophy, and beyond. - Geocritical Explorations: Space, Place, and Mapping in Literary and Cultural Studies. Toim Robert T. Tally Jr. New York: Palgrave Macmillan, lk 13-27.

Priid el, Endel 1968. Piki Peipsi piiri. Tallinn: Eesti Raamat.

Ri d a la, Villem 1921. Ringi mööda kodumaad. Tallinn: Maa.

Rohrbach, Paul 1892. Die Schlacht auf dem Eise: Eine Deutsch-Russische Entscheidung im Jahre 1242. Berlin.

Sam s on - Hi m m els tj er n a, Fred Ottokar von 1944. Nebel am Peipussee. Stuttgart: Aehre.

Silla ots, Marta 1921. Kodukäijad: jutustused ja pildid. Tallinn: Maa.

Sive r s, Jegor Julius von 1846. Die Schlacht auf dem Peipus. - Balladen und Lieder. Dorpat: Franz Kluge'sche Buchhandlung, lk 7-16. http://dspace.utlib.ee/ dspace/handle/10062/6002 (1. VIII 2016). 
Soja, Edward 1996. Thirdspace: Journeys to Los Angeles and Other Real-and-

Imagined Places. Oxford: Blackwell.

S o ov äli, Helen 2008. Kultuurigeograafia. - Keel ja Kirjandus, nr 8-9, lk 654-664.

Sõnarine. Eesti luule antoloogia. 1. kd. Koost Karl Muru. Tallinn: Eesti Raamat, 1989.

Ši šk ov, Vjatšeslav 1926. Sealpool Peipsit. Leningrad: Edasi.

Tally, Robert Jr. 2013. Spatiality. The New Critical Idiom. London-New York: Routledge.

Tugl a s, Friedebert 2013. Kogutud teosed 12. Juhan Liiv. Tallinn: Underi ja Tuglase Kirjanduskeskus.

Valli s o o, Mari 1983. Rändlinnud kõrvaltoas. Tallinn: Eesti Raamat.

Vall i s o o, Mari 1991. Sünnisõnad ja surmasõnumid. Tallinn: Eesti Raamat.

V all i s o o, Mari 2013. Viimäne vihim. Tartu: Ilmamaa.

Valli s o o, Mari 2015. Mälestusi maailmast: 1966-2013. Tartu: Ilmamaa.

Westphal, Bertrand 2011. Geocriticism: Real and Fictional Spaces. New York:

Palgrave Macmillan.

Woltmann, Johann Friedrich August Ludolf 1833. Beschreibung einer Reise nach St. Petersburg, Stockholm und Kopenhagen. Hamburg: Hoffmann und Campe.

\section{A geocritical approach to literature written about Lake Peipus}

Keywords: geocriticism, literary theory of space, comparative literary studies, Bertrand Westphal, Peipus-literature.

The aim of the article is to analyse literature related to Lake Peipus from the perspective of geocriticism.

First, the article gives an overview about geocriticism and a brief introduction to its origins, that is, the spatial turn of the $1980 \mathrm{~s}$.

The second part of the article has its focus on Bertrand Westphal's theory, especially the four elements of geocriticism: multifocalization, polysensoriality, stratigraphic vision and intertextuality. According to the principle of multifocalization, the geocritic is required to engage with many different points of view. Polysensoriality means that it is not only the visual landscape that is important but landscape as sensed with all senses. Stratigraphic vision means that topos is understood to comprise multiple layers of meaning. Intertextuality shows how a place is full of connections between different texts. All these elements are illustrated with examples from Peipus-literature.

The third part of the article analyses the symbolic meanings that emerge from Peipus-literature. The symbolic meanings of Lake Peipus can be divided into three groups: Lake Peipus as an environment (a space/place), Lake Peipus as a border or a communication route (a non-place), and Lake Peipus as a sanctuary or someone's destiny (a non-geographical entity). In the analysis I primarily focus on which meanings seem more important to local authors and which ones to those who have visited the lake only once or just a couple of times.

In conclusion, Lake Peipus is still mainly the landscape of Juhan Liiv's oeuvre.

Evelyn Fridolin (b. 1990), MA in World Literature; student of Applied Architecture at TTK University of Applied Sciences, evelynfridolin@gmail.com 